\title{
Mongolia-Central Asia relations and the implications of the rise of China on its future evolution
}

\author{
John Irgengioro ${ }^{1}$ (i)
}

Accepted: 2 December 2021 / Published online: 21 February 2022

(C) The Author(s), under exclusive licence to Springer Nature Limited 2022

\begin{abstract}
This article provides an analysis of Mongolia's foreign relations with the postSoviet Central Asian states, particularly with Kazakhstan and Kyrgyzstan, and their prospects going forward. It provides an overview of relations and analysis of why, despite shared geocultural identities and geopolitical imperatives, their relationship remains more distant than Mongolia's relations with its other neighbors of East Asia. It then assesses the changes brought by the dynamics of a rising Chinese power projection as manifested through its Belt and Road Initiative in the region, and, using the IR theories on rising powers and weak state behavior, examines the impetus of these shifting dynamics for future Mongolia-Central Asia relations.
\end{abstract}

Keywords Mongolia $\cdot$ Kazakhstan $\cdot$ Kyrgyzstan · Mongolia-Central Asia relations · Small states regionalism $\cdot$ Foreign policy

\section{Introduction}

While Mongolia is usually recognized currently as a part of East Asia, at least politically speaking (UNstats 2021; Worldbank 2021), this country is significantly different in almost all aspects from other East Asian nations of China, the Koreas, and Japan-in terms of differences in geopolitical and geo-economics situations, as well as being fundamentally distinct in its cultural identity-but have been increasingly drawn toward East Asia since the end of the socialist period politically and economically. Meanwhile, this article will also show that although Mongolia have much in common with the post-Soviet Central Asian states to its west-especially with Kazakhstan and Kyrgyzstan, in terms of similar geopolitical and geo-economic situations as well as shared cultural identities, relations with this region remained stagnant over the past century, and current governmental, economic, and peopleto-people relations remain minimal. Why is this the case, and how are the future

John Irgengioro

john.irgengioro@ugent.be

1 Ghent University, Ghent, Belgium

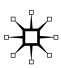


prospects of Mongolia's relations with Central Asia? This article takes a look at Mongolia's current foreign policy and ideational situation vis-a-vis its neighbors and current Mongolia-Central Asia relations, and assesses the potential of and interests for relations with the Central Asian states of Kazakhstan and Kyrgyzstan, especially in light of the implications posed by China's Belt and Road Initiative (BRI) across the Eurasian landscape. It thus first provides a background overview of Mongolia's geopolitical position and of Mongolia-Central Asia relations up to the present, and then conducts an analysis of the implications that China's BRI ambitions have for a new chapter of Mongolia-Central Asia relations, through the use of International Relations theories on rising powers, weak states, and alliance formations.

\section{Mongolia between Central and East Asia}

Mongolia's current geopolitical political position is indeed an outlier. Physically sandwiched between the two great powers of Russia and China, it struggles to define its own geopolitical position on the world stage, as one Mongolian official describes their country as "a hybrid of Central and East Asia" (Pieper, 2020b, p.2). International bodies such as the United Nations statistical division categorize it as being a part of the region of East Asia, but Mongolia differs greatly from the other East Asian countries in terms of demographics, geography, and economic situations, not to mention as cultural and identity differences. First, this sparsely populated country of just over three million people is greatly dwarfed in population compared to the other East Asian countries of China (around 1.4 billion), South Korea (51.5 million), North Korea (25.5 million), or Japan (126.8 million) (UNstats, 2021), making Mongolia a much smaller country demographically. Second, the country's landlocked geographic situation in the middle of Eurasia differs from the three major East Asian powers with their coastal access to the Asia-Pacific, thus presenting a different set of geopolitical imperatives. Third, the country's economic situation is very different from that of China, South Korea, or Japan, with the East Asian giants possessing large, globally competitive diversified economies while Mongolia's small economy is dependent on resource extraction. Finally, the country's culture, drawing upon its nomadic heritage, Tibetan Buddhist influences, and Soviet-dominated socialist legacy contrasts sharply with the Confucian cultural sphere of East Asia and its differing historical trajectories and experiences.

Meanwhile, one can find much similarities between Mongolia and Central Asian countries, especially with Kazakhstan and Kyrgyzstan-Central Asian countries with whom Mongolia not only shares certain cultural identity legacies, but also modern-day geo-economic and geopolitical dynamics. The current definitions of Central Asia being the five post-Soviet "Stans" are themselves a Russian and Soviet conceptualization, since adopted by the rest of the world, for the areas in the region under Russian control rather than by its intrinsic geographical, cultural, or economic properties (Starr 2008, p.4), and Mongolia itself is considered as part of the greater Central and Inner Asian geocultural space and part of a common steppe world (Laruelle 2018; Starr 2008. The contemporary situation of Mongolia being linked to Central Asia by physical or cultural geography while being physically cut 
off from modern Central Asian states is thus instead the result of the absorption of huge territories of historically Inner Asian space -such as the regions of Xinjiang, Inner Mongolia, and the Tibetan plateau-by the Chinese state into its modern borders (Millward 2007), which cuts Mongolia off from a physical link with the Central Asian states in the present day. Nevertheless, in terms of culture and self-identity, Mongolia exhibits much in common with Central Asia, especially with Kazakhstan and Kyrgyzstan, in cultural attributes such as customs, clothing, music, food, lifestyle, or architecture, which are legacies of their common nomadic past. Meanwhile, in the case of differences in the traditional religions-Islam for ethnic Kazakh and Kyrgyz, Tibetan Buddhism for ethnic Mongols-scholars underline that the adherence to these religions by all three peoples are historically nominal as these ethnicities all incorporate a large mix of Tengriist and steppic culture into their traditional ethnic identities (Laruelle 2019; Yemelianova 2014, p.2; Artman 2019; Myadar \& Rae 2019). Mongolia also shares, to a certain degree, the Soviet or socialist legacy with Central Asia, although the imprint of Russification was not as strong in Mongolia since was not a part of the Soviet Union like Kazakhstan or Kyrgyzstan, was but one of the USSR's "satellite states" as the Mongolian People's Republic (1921-1992). Finally, and perhaps most importantly, the three states share many geopolitical and geo-economic imperatives. First, all three countries are landlocked and border China, and, except for Kyrgyzstan, border Russia as well. Meanwhile, Kazakhstan and Kyrgyzstan border other Central Asian countries, while Mongolia does not border any other country at all besides China and Russia-its closest point to Kazakhstan at around $37 \mathrm{~km}$ away being cut off by a China-Russia border in between them in the Altai Mountains. This means that Russia and China thus looms large in the foreign policies of all three countries, consider, a state of affairs which also holds true for Kyrgyzstan, without a direct border with Russia, since it retains deep linkages and dependencies with the successor state of the former Soviet Union and is member to a number of Russia-led international organizations and alliances (Laruelle 2014). Thus, in terms of foreign policy, all three countries, as smaller, weaker powers wedged between China and Russia, must pursue their own national interests in the face of these great powers neighbors and have to choose between four general options in terms of their foreign policy: aligning themselves with either Russia or China, pursue a policy of neutrality, such as in the example of Switzerland, pursue a policy of reaching out to external powers further afield, such as Mongolia's current "third neighbor policy," or seek to balance the interests of the great powers through increasing partnership among themselves (Batbayar 2002, p.333). In terms of economic situation, Kazakhstan, Kyrgyzstan, and Mongolia also have much in common. The economies of all three countries fall into lower-middle to middle-income groups by global standards (World Bank 2021), and resource extraction makes up a prominent part of all three economies-with Kazakhstan's exports being dominated by the oil and gas sector as well as various metals, while Kyrgyzstan and Mongolia, lacking more lucrative endowments of oil and gas, are mostly limited to other mineral extractions-with gold and other types of mineral ore products comprising more than half of Kyrgyzstani exports, while coal and copper dominate the exports of Mongolia (Observatory of Economic Complexity 2021). All three countries are thus developing economies with a dependency 
on resource extraction, although Kyrgyzstan's economy is relatively more diversified than Mongolia or Kazakhstan's with more balanced agricultural and light manufacturing sectors (ibid). Thus, we can see that the country profiles of the Central Asian countries of Kazakhstan and Kyrgyzstan have much in common with Mongolia: The three countries share deep historical and cultural identity ties rooted both in their common steppe identity and Soviet influence, they are all located in relatively close proximity in the greater Central Asian neighborhood between China and Russia and share the imperative of the pursuit of their own interests and maintenance of their sovereignty between the great powers and are also all smaller, developing nations dependent on resource extraction.

\section{Mongolia-Central Asia Relations-a relationship that never was?}

Given the similar country profiles and shared national imperatives, it would seem intuitive if Mongolia maintains a close relationship with the Central Asian states, particularly with Kazakhstan and Kyrgyzstan. However, this is far from the case, and the relationship between Mongolia and the Central Asian countries remains distant in comparison with its East Asian neighbors. An overview of the evolution of Mongolia's relationship with Kazakhstan and Kyrgyzstan is as follows:

\section{Mongolia's geopolitical vision and Mongolia-Central Asia relations up to the 1990 s}

While historically Mongolia have had intimate links with the lands that is currently the Central Asian "Stans" since the days of the Mongol Empire, when the area was under the rule of the Golden horde and the Chagatai Khanate, and continuing into the later intensive contacts between various Western Oirat Mongols and the Kazakh khanates (Millward 2007), contacts between the Eastern Mongols of today's Mongolia with Kazakh and Kyrgyz people were evidently scant during the centuries of Manchu Qing rule in Mongolia, during which the Qing Dynasty's borders isolated it from other regions to its west. Modern relations between Mongolia and Central Asian republics commenced in the socialist era, while Mongolia was a Soviet satellite and the Central Asian republics were part of the Soviet Union, but this was largely conducted within the framework of the former Soviet Union as a whole and did not really involve independent policymaking on the part of the Central Asian republics then under the Soviet Union (Soni 1996, p.173). It thus wasn't until the breakup of the former Soviet Union in 1991 and the independence of Central Asian states that foreign relations between Mongolia and Central Asian countries of Kazakhstan and Kyrgyzstan began in earnest (ibid, p.174).

The period in the 1990s was a time of uncertainty and optimism for all three countries, a time when scholars argue all of them achieved real independence for the first time-Mongolia finally achieving de facto independence in foreign policy following the period of the Mongolian People's Republic as satellite state of the Soviet union since its establishment in 1921, while Kazakhstan and Kyrgyzstan achieved 
both de jure and de facto independence after the collapse of the USSR (Batbayar 2002, p.325; Soni 1996, p.174). During the 1990s, there was significant speculation among Mongolian politicians and academia as for what foreign policy routes Mongolia will take given its newly found independence, the country's geopolitical grand strategy, and even the country's national identity in terms of its geographical and cultural aspects. Batbayar (2002), for example, discussed the concept of a "geopolitical vision" for Mongolia and argued that it is intrinsically linked to Mongolia's national identity, which includes both geographical and cultural factors (Batbayar 2002, p.324). The question of Mongolia's geographical and cultural identity was used to determine Mongolia's geopolitical positioning in the region and boiled down to whether Mongolia should be considered as a Central Asian or East Asian country. This, as Batbayar argued, "was not merely an academic exercise, but ones with implications for Mongolia's survival as a sovereign state" (Batbayar 2002, p.328), since Mongolia is located at the crossroad of Russia to the North, East Asia to the East and South, and Islamic Central Asia to the West, where the choice of Mongolia's geopolitical orientation will have important consequences going forward. On one camp, there are scholars like Baabar who believe that Mongolia is a part of Central Asia and favors an alignment of Mongolia with other Central Asian countries, where such conceptualizations with Central Asia in the 1990s had a strong civilizational and cultural identity aspect to it. Indeed, Baabar's conception of Central Asia includes not only Mongolia and the five post-Soviet Stans, but also regions like Xinjiang, Tibet, Buryatia, Tuva, and countries like Afghanistan, Azerbaijan, and Turkey, and is based on the idea that Central Asia means the region at the heart of the Asian continent, historically a region of the meeting point of cultures on the Silk Roads, possess much diversity in aspects such as religion or topography, and currently existing as smaller entities located in between major peripheral powers such as Russia or China, thereby sharing common historical and cultural affinities as well as geographical imperatives (Baabar 1995, p.18). Baabar thus advocated for a "Central Asian Security Zone" in order to secure their common interests (ibid, p.25). In the other camp, however, were thinkers who argue that Mongolia's geopolitical alignment need not only a civilizational/cultural aspect, but more importantly a clear developmental aspect as well (Batbayar 2002, p.329), and the former diplomat Kh. Olzvoy thus called for Mongolia to not align itself with Central Asia, but with Northeast Asia instead. This, he argued, is because the Central Asia states are essentially not very useful for Mongolia's developmental goals, as they are another group of landlocked states which cannot provide much complementary benefits. The region's recent independence from the Soviet Union means that it has yet to become politically and economically stable, and the state of its underdeveloped economy, similar to that of Mongolia's while being economically intertwined with Russia, offers few opportunities for Mongolia's benefit (Olzvoy 1996, p.54). In contrast, Olzvoy argued that an alignment with Northeast Asian countries would be much more beneficial. Northeast Asian countries such as Japan and South Korea have already developed into advanced economies by the 1990s and China was also obviously on the ascent economically by then. Furthermore, cooperation with the Northeast Asian countries with coasts on the Pacific will allow Mongolia to access markets worldwide and thus remedy its landlocked status (Olzvoy 1996, p.55). It is thus in this context of the 
political debate between the alignment of Mongolia as a Central Asian or East Asian country that Mongolia's Concept of Foreign Policy was endorsed by the Mongolian parliament in 1994, a document which emerged as a compromise between those who advocated for a Central Asian identity versus those who advocated for an East Asian identity, and thus subsequently formed Mongolia's "geopolitical vision, mentioning that both Northeast and Central Asia will be focuses of Mongolia's foreign policy" (Batbayar 2002, p.331).

Mirroring these theoretical foreign policy debates, Mongolia's relations in the 1990s with Central Asia in practice was also in a state of uncertainty and anticipation. After the Central Asian republics gained independence, Mongolia seemed interested in building relations with three of the Central Asian countries: Kazakhstan, Kyrgyzstan, and Uzbekistan-motivated in part by their perceived closer historical and cultural ties (especially a common steppic heritage with Kazakhstan and Kyrgyzstan), while relations with the other two Central Asian countries were less feasible - as Turkmenistan was cited as being too remote and already pursuing an isolationist foreign policy, while Tajikistan was in the middle of a civil war (Soni 1996, p. 177). During this period, there have been significant attempts at consolidating relations between Kazakhstan and Mongolia. The two sides established direct road links across the Altai Mountains and airline service between Almaty and Ulaanbaatar, while Kazakhstan's president first visited Mongolia in 1993 and commenced several agreements concerning economic and cultural cooperation and a protocol on cooperation between the foreign policy departments and national banks of Kazakhstan and Mongolia. Moreover, mutual trade volumes between the two countries steadily increased, reaching more than 25 categories of goods by 1996, with Mongolia exporting textiles, wood, animal products, and consumer goods to Kazakhstan while Kazakhstan exports machine tools, tires, spare parts, and petroleum products to Mongolia. The two sides also concluded several agreements on the "repatriation" of Mongolian Kazakhs to Kazakhstan as well as guaranteeing their rights of freedom of movement and citizenship (Soni 1996, p.175-176). Meanwhile, Mongolia's relationship with Kyrgyzstan commenced with the official visit of Kyrgyzstan's president Askar Akayev to Mongolia in 1993, where several agreements including a treaty of friendship and cooperation were concluded, and during this time Mongolia also commenced trade relations with Uzbekistan (Soni 1996, p. 177). Thus, the initial relations between Mongolia and the Central Asian countries were promising, with Mongolia being more of an objective for the newly independent Central Asian countries' outreach than vice versa.

\section{The long stagnation: Mongolia-Central Asian relations towards the present}

However, despite initial promises, relations between the Mongolia and the Stans have remained relatively stagnant. For instance, the direct flights between Almaty and Ulaanbaatar were cancelled by the 2000s, citing lower passenger volumes, and direct Mongolia-Kazakhstan flights were not reinstated until 2019, while Mongolia's general consulate in Tashkent was downgraded to become an honorary 
consulate afterwards as well. In the first decade of the twentieth century, Mongolia and Kazakhstan exchanged state visits just once, as well as a few visits at the minister level-from Kazakhstan, state secretary in 2005 and Minister of foreign affairs in 2006, and from Mongolia, Secretary of national security council in 2000, and vice prime minister in 2006 and 2007 (Kazakhstan Ministry of Foreign Affairs, 2021). Mongolia's official contacts with Kyrgyzstan, meanwhile, has been even less scant. For instance, in terms of inter-parliamentary relations, there have been just one visit from the chairman of the State Great Khural (parliament) of Mongolia to Kyrgyzstan, and just three visits from speakers and vice speakers of the Kyrgyzstani Jogorku Kenesh (Supreme council) to Mongolia between the years 2004 and 2011 (Badral 2017), while Mongolia only established an embassy in the Kyrgyzstani capital in 2019 (Batchimeg 2019). In terms of economic relations, Mongolia's trade volumes with Kazakhstan and Kyrgyzstan are also unimpressive as well as of an irregular nature throughout the years. As bilateral trade statistics show, ${ }^{1}$ the previous decade saw a long stagnation of still miniscule trade volumes, which also appears to be an extremely lopsided trade imbalance in favor of Kazakhstan, and to a lesser extent, for Kyrgyzstan as well. For instance, in the year 2019 Kazakhstan exported goods such as foodstuffs, vegetable products, animal products, and machinery to Mongolia for a turnover value of $\$ 58.1$ million, while Mongolia only exported a turnover value of $\$ 7.14$ million, mostly in transportation equipment, paper goods, or animal products. Meanwhile, Mongolia's trade relations with Kyrgyzstan are also imbalanced, where in 2019, for instance, Kyrgyzstan exported goods to Mongolia to the value of \$2.32 million while Mongolia only exported goods to Kyrgyzstan to the value of $\$ 413$ thousand. Other trade patterns between Mongolia, Kazakhstan, and Kyrgyzstan can also be observed: Kazakhstan and Kyrgyzstan have a more diversified set of exports to Mongolia with more value-added products, while Mongolia export to Kazakhstan and Kyrgyzstan mostly animal and resource products, with occasional spurts of machinery. In addition, Mongolia's exports to Kazakhstan and Kyrgyzstan are more irregular in terms of turnover value and products exported, which is the result of relatively very small volumes being traded, where Mongolia's exports to Kyrgyzstan are at a negligible level. It is thus clear that current economic relations between Mongolia and Kazakhstan and Kyrgyzstan are minimal and largely stagnant.

Such paltry economic figures pale in comparison with Mongolia's trade with the East Asian giants of China, South Korea, or Japan which have been ever increasing before the COVID-19 pandemic. For instance, in 2019, imports from China made up a total value of $\$ 1.95$ billion, comprised of a very diversified and complex import mix of machines, metals, transportation, electricity, chemicals, foodstuffs, and almost every other category of goods; imports from South Korea amounted to \$287 million, of also very diverse categories such as machines, transportation equipment,

\footnotetext{
1 See Tables and Figures section: Mongolia exports to Kazakhstan by year, by (value \$) and by breakdown of exported goods; Kazakhstan exports to Mongolia by year, (by value \$) and by breakdown of exports goods; Mongolia exports to Kyrgyzstan by year, by (value \$) and by breakdown of exported goods; Kyrgyzstan exports to Mongolia by year, (by value \$) and by breakdown of exports goods. Author's own work.
} 
foodstuffs, and chemical products; and imports from Japan amounted to \$594 million, mostly transportation vehicles and machines. Meanwhile, Mongolia exported a whopping \$6.59 Billion worth of goods to China, mostly extractive metals, \$34.7 million to South Korea, mostly textiles and extractive minerals, and \$20.8 million to Japan, mostly extractive minerals and textiles (UN Comtrade 2021; Observatory of Economic Complexity 2021). Drawn by East Asia's economic might, Mongolia is thus very dependent on trade with the East Asian countries currently while having relatively little economic ties with Central Asian Kazakhstan and Kyrgyzstan.

Meanwhile, the people-to-people relations between Mongolian and Central Asian publics are also evidently distant. For instance, in terms of mutual tourism, relatively low number of Mongolian tourists visit Kazakhstan or Kyrgyzstan and vice versa. Citizens from Kazakhstan made up 16,264 of tourist arrivals in Mongolia in 2019 (Visit Ulaanbaatar 2019), while citizens of Kyrgyzstan make up an even smaller number such that it was not listed among prominent countries of arrival by Mongolia's tourism board (ibid). Vice versa, only 20,700 Mongolian citizens visited Kazakhstan in 2018 and an even smaller amount visited Kyrgyzstan not sufficient to be individually listed (National Statistics Committee Kyrgyzstan 2017). These are much lower numbers than the amount of Mongolian citizens visiting East Asian countries, where approximately 1,494,300 Mongolians visited China in 2018 (China National Bureau of Statistics 2019) and 113,864 visited South Korea in 2018 (Korea Tourism Association 2019). Furthermore, Mongolia's educational relations with Kazakhstan and Kyrgyzstan are currently almost nonexistent: for example, in 2017, only around 250 Mongolian citizens have been accepted to study in Kazakhstan's higher learning educational institutions (Enkh-Orgil 2017), while between 2013 and 2017 only 32 Mongolian citizens studied in Kyrgyzstan's higher education institutions (Stat.kg 2021). In contrast, more than 7300 Mongolian students were studying in South Korea in 2018, making up the third largest international student group in that country, while 10,100 Mongolian students study abroad in China in 2018, thus being the biggest study abroad destination for Mongolian students (ICEF Monitor 2019). The relative lack of people-to-people interaction in terms of tourism and educational metric thus helps to keep Mongolians unfamiliar with Central Asian countries, and vice versa.

What explains this current situation of Mongolia's relatively low connectivity between Mongolia and Central Asia while being much more connected with East Asia? This article argues that while the strong pull of economics from the booming East Asian economies can be a clear explanation for Mongolia's increasing orientation eastwards, the lack of Mongolia's connectivity to Central Asia can be explained by two factors. First, as Mongolia's status as a former Soviet satellite state but not part of the USSR proper corresponded to its relatively lesser degree of Russification, the English language thus quickly replaced Russian as the new language of cosmopolitanism in the country since the post-socialist era (Bille 2010; Cohen 2005), a phenomenon which, in contrast to the continued dominance of the Russian language as a lingua franca in Central Asia (Skalamera 2017), becomes a liability factor for Mongolia in terms of building people-to-people ties with Central Asia and the post-Soviet space. Second, Mongolia's subsequent lack of material incentives and geopolitical vision for building relationships with Central Asia 
further discouraged their political cooperation, as the East Asian giants' more attractive economies and economic clout resulted in Mongolia's gravitation toward economic integration and dependency with East Asia. Another explanation attributes the lack of economic relations to the supposed lack of economic complementarity due to the similar export structure among Mongolia, Kazakhstan, and Kyrgyzstan, with all three countries being all relatively dependent on the export of various natural resources (although to a lesser extent in Kyrgyzstan), but the lack of economic connectivity cannot entirely be blamed on the lack of economic synergies, since the Central Asian states are also economically similar between each other to a large extent, and, though far from being an integrated region among themselves (Krapohl \& Vasileva-Dienes, 2020), still demonstrate higher integration metrics with each other than with Mongolia. For instance, just like the situation between Mongolia and Central Asia, Tajikistan and Kazakhstan also share direct no land borders with each other and both countries also have largely resource extraction-based economies, yet they are still among each other's top three trade partners in 2019 (Observatory of Economic Complexity, 2021). Furthermore, the assumption of a low level of economic potential between Mongolia and Central Asia can itself be challenged, as Marlene Laruelle illustrates that, for example, Mongolia and Kazakhstan have many promising mutual economic interests, but these have strikingly yet to be materialized (Laruelle 2018, p.405).

The lack of people-to-people connections is perhaps the most telling, which cannot be fully attributed to the lack of a land border between Mongolia and the Central Asian states, since Central Asian states which do not share land borders with each other still enjoy more people-to-people traffic than with Mongolia, as is the case between Kazakhstan and Tajikistan (Stat.gov.kz, 2021). The persistent lack of political relations, economic ties, and people-to-people connections should thus mostly be attributed societal circumstances, a current lack of geo-economic incentives, as well as a lack of popular consciousness and political will between Mongolia and the Kazakhstani and Kyrgyzstan public in building closer relations. For country(ies) on either sides of the Altai Mountains, those on the other side are thus far still perceived as distant, unfamiliar countries with a common heritage but lacking in modern-day economic and political relevance.

\section{The China factor: Belt and Road Initiative, the rise of China, and implications for future Mongolia and Central Asia relations}

Recently, however, the geopolitical situation across Central Asia and Mongolia is undergoing major changes due to an external factor - the rising power of China and its increasing clout in the region. In 2013, China announced the "Silk Road Economic Belt" (SREB) project in Astana (now Nur-Sultan), Kazakhstan-the land component of an initiative of which was later combined with its counterpart, the "Maritime Silk Road" to form its ambitious Belt and Road Initiative (BRI). The BRI thus became a collective branding of an assortment of infrastructure and economic integration projects with the stated goals of promoting connectivity along the New Silk Road in terms of "policy coordination, infrastructure connectivity, 
trade facilitation, financial cooperation, and people to people contacts" (Bitabarova 2018) between China and the rest of the Eurasian continent and beyond; the largest Chinese-led Eurasian integration effort to date and a defining piece of China's global foreign policy in the Xi Jinping era (Fallon, 2015; Cooley 2016; Chen, 2015). Strands of the literature have since emerged analyzing China's motivations behind the BRI, including its theoretical underpinnings from the "Xijin" or "March West" strategy — a rethinking of Chinese geopolitical strategy calling for a rebalance from China's concentration on great power diplomacy and the Asia-Pacific region toward a greater focus on the Eurasian continent and peripheral diplomacy, as advocated by the prominent Chinese scholar Wang Jisi, in order to break through China's increasingly zero-sum game with the US and Asia-Pacific rim powers and give China new global leverage (Wang 2011; Pantucci 2015; Bitabarova 2018, p. 155), as well as being a Chinese geostrategic grand design to remake the Eurasian, and subsequently global, order in its own image and heralds its arrival as an Eurasian power (Mayer 2018; Panucci \& Lain 2017; Cooley 2016; Fallon 2015).

Straddling the geographical links between China and Europe and Western Eurasia, Mongolia and the Central Asian states thus became important considerations of the envisioned SERB economic corridors linking China to Europe and Western Eurasia, which include: (1) the Northern Eurasian corridor of China-Mongolia-Russia-Europe, (2) the Central Eurasian corridor, or New Eurasian land bridge, of Western China-Kazakhstan-Russia-Europe, (3) the Trans-Caspian corridor (Western China-Kazakhstan-Azerbaijan-Georgia-Turkey/Europe via the Caspian sea), (4) the Trans-Asian corridor (Xinjiang-Kazakhstan-Turkmenistan-Iran), as well as (5) the "Southern corridor" (s), the less clearly formulated Xinjiang-Kyrgyzstan-Uzbekistan corridors which goes onward toward the Middle East (Vinokurov et al. 2018; Chatzky \& Mcbride 2019; Chubarov 2019, p.85). As these economic corridors all involve the Central Asian states or Mongolia, this region collectively occupies an essential role in China's BRI ambitions. Kazakhstan, in particular, have been identified by scholars as being the SREB's key cooperation partner in the region as it forms the lynchpin of two major SREB economic corridors across Eurasia, and is thus a critical actor for Chinese geo-economic and geopolitical strategy (Bitabarova 2018; Pieper 2020a).

\section{Reactions of Mongolia, Kazakhstan, and Kyrgyzstan to the BRI}

From the perspective of Mongolia and the Central Asian states, China's BRI and increasing presence in the region can hardly be overstated, as it is evident that it brings an assortment of opportunities, concerns, and ultimately, fundamental changes in regional dynamics for these states. On the one hand, scholars note that, as landlocked states in the middle of Eurasia hampered by a lack of global connectivity and developmental challenges, the geo-economic lure of the BRI for Kazakhstan, Kyrgyzstan, and Mongolia is proving to be decisive, as these environed economic corridors may provide them with the opportunity to ameliorate their geographical and developmental woes to become important nodes on the economic corridors of the new Eurasian silk road (Bitabarova 2018; Pieper 2020a, 2020b). Indeed, all three 
states have demonstrated agency in officially embracing these SREB economic corridors since China first proposed them, as they see the SREB being aligned with their own domestic developmental interests (Bitabarova 2018; Pieper 2020a, b; Mogilevskii 2019). For instance, the crystallization of the China-Mongolia-Russia corridor passing through Mongolia was in fact spearheaded by the Mongolian government's own efforts in not wanting to be left out of the initiative (Pieper 2020b, p.2), while Kazakhstan and Mongolia developed or seek synergize their own domestic programs alongside China's BRI. Following the BRI's announcement, Kazakhstan went beyond a mere passive response to China's grand proposal by seeking to "link up" the BRI to the country's already existing domestic development program, "Nurly Zhol," or "Bright Path" (Pieper 2020a, p.1), while Mongolia presented its own connectivity program, "Tallin Zam" or "Steppe road," after the announcement of the BRI as a complementary project (Pieper 2020b, p.2).

The welcoming of the BRI by all three governments is fueled by the perception that the BRI's investment projects can potentially provide their countries with the much needed infrastructure and industry developments boosts needed all across the region, as well as in conjunction with their own domestic developmental goals. Scholars argue that Kazakhstan see the BRI as not only matching its own vision of becoming a lynchpin on the modern silk road, but also an instrument in aiding its own urgent efforts in upgrading its domestic transportation infrastructure to better integrate the country's own macroregions amidst pressures from the downturn of the country's oil dependent economy since 2015, as well as a further interest in utilizing the BRI to spur Kazakhstan's own manufacturing capacity and economic diversification through Kazakh-Chinese industrial cooperation, in order to diversify beyond mostly energy exports to include other promising sectors such as agriculture (Bitabarova 2018; p.161-168; Bizhanova 2018; Pieper 2020a). Kyrgyzstan possess much less resources of its own while also having dire needs in improving its insufficient infrastructure and developmental needs, and have thus also welcomed a number of joint initiatives and investments under China's BRI umbrella, including many key infrastructure projects in its transportation networks, energy infrastructure, and urban development, as well as FDI in local resource extraction (Mogilevskii 2019). Mongolia, meanwhile, also seek synergy with the BRI in its objective of updating its poor transportation infrastructure and gain better access to Chinese ports for Mongolia's trade with third countries, and understanding that the three top priorities of the trans-Mongolian corridor are road development, railway infrastructure, and the development of Mongolia's energy sector (Pieper 2020b).

However, beneath the official embrace of the BRI by all three countries for its anticipated economic benefits, there are wearier perceptions, especially across the public level across Central Asia and Mongolia, whom often express more reservations, concerns, and in many cases, increasing negative sentiments toward the SREB projects and the trajectory of future relations with China in general. Projects undertaken in recent years under the BRI banner across Central Asia have already fueled a myriad of public concerns on the implications of increasing Chinese investments and China's growing clout in the region, such threats of Chinese ownership of local land, debt traps from borrowing from the large-scale BRI projects beyond the limited capacities of Central Asian states, the enablement of the BRI projects as sources 
of corruption, a limited contribution of Chinese investments toward local job creation, or long-term concessions to Chinese interests (Pieper 2020a; Kruglov 2019). While China now seem to be diversifying away from large infrastructure projects in the face of their criticism toward more investments in local industrial projects (Van der Kley 2021), the already implemented joint industrial projects, in Kazakhstan, for instance, are still subject to increasing concerns on their opacity, relationships with corruption, or environmental damage (Bitabarova 2018, p.168). It doesn't help that the BRI "investments" from China, as Pieper dissects, are usually schemes to lend money to the recipient governmental authorities, which they then have to reinvest to secure contracts with Chinese engineering firms, and the money thus hardly leaves the Chinese system and further provides the negative impression that Chinese actors' interests lie in building and owning assets in the target country and slowly gaining leverage (Pieper 2020a). Meanwhile, the current track record of China's BRI projects on the ground seems to do little to nullify negative perceptions toward them, demonstrated by cases such as a corruption-rooted power plant breakdown scandal in Kyrgyzstan (Higgins 2019), the perpetuation of unscrupulous behavior by Chinese companies operating under the BRI banner (Yau 2019), or persistent concerns about pollution from Chinese run factories (Imanaliyeva 2020). Furthermore, fears over debt trap diplomacy is a serious concern for the limited capacities of the small states of Central Asia and Mongolia, whom, in any case, prefers more international funding as opposed to Chinese policy bank funding which China seems to insist on in the region (Pieper 2020b). In fact, the threat of a debt crisis to China is already becoming a reality in the case of Kyrgyzstan, where debts accrued to China's Export-Import Bank for a series of BRI-branded projects have already swelled to over 40 percent of Kyrgyzstan's national debt, while Kyrgyzstan's struggling economy since the COVID-19 pandemic has threatened the country's ability to even make the interest payments (Standish 2021). In the face of such developments, it is perhaps not surprising that in Kazakhstan and Kyrgyzstan, which received more of a surge of increasing Chinese BRI presence in recent years, the negativity against this has already fueled public protests, in some cases violent, against BRI projects and Chinese nationals (Yau 2020; RFE/RL 2020, Umirbekov 2019).

But perhaps the biggest concern relating to the BRI and China's growing clout across Central Asia and Mongolia is the threat of embedded conditionality and growing Chinese political leverage resulting from the BRI and closer ties with China. While Beijing have long claimed a principle of non-interference in the internal affairs of other sovereign countries (Kivimaki 2014, p.433) and present economic cooperation with China as being win-wins without any sort of governance conditionality, which indeed is one of its key posturing differentiation toward third countries vis-à-vis Liberal Western states (Grieger 2015; Wilson 2015), China's records of dealing with Central Asia and Mongolia increasingly show embedded conditionality of their own. In Kazakhstan, the increasing clout of China has corresponded with the Kazakhstani government's increasing subservience to Beijing's position on what Chinese deems as its sensitive political issues-such as the political crackdown in Xinjiang in which hundreds of thousands of ethnic minorities, including many ethnic Kazakhs, have since been incarcerated and subject to gross levels of human rights violations - as Kazakhstan ceases to be any sort of safe haven 
for asylum seekers and, amidst pressure from Beijing, imprisons its civil society activists campaigning on this matter (Rickleton 2020; 2021). Meanwhile, the direct political consequences of a hegemonic Chinese economic leverage in Mongolia, pervasively increasing since its post-socialist era, can already be demonstrated since the advent of the BRI with cases such as the Dalai Lama scandal. A Tibetan Buddhist nation by heritage, Mongolia have previously hosted the Dalai Lama, the Tibetan spiritual leader viewed by China as an "anti-Chinese separatist" many times in the past, but China responded to the latest visit to Mongolia by the Dalai in 2016 with an economic blockade of Mongolian exports, and under such pressure, the Mongolian foreign minister made a remarkable public apology to Beijing promising to not allow any further visits by the Dalai Lama under the current administration, with Beijing following up by admonishing Mongolia that it should "truly learn" from this experience and respect China's "core interests"(Kohn 2016; Radchenko 2017). In light of Mongolia's already overwhelming economic dependence on exports to China (Observatory of Economic Complexity, 2019), such responses are perhaps not surprising, but, as Sergey Radchenko argues, Mongolia's humiliating apology thus cuts into the heart of Mongolia's sovereignty, emboldens China to act in an even more brazen manner in its neighborhood, and sets a dangerous precedent for Mongolia's future where any foreign policy action by Mongolia can be subject to Chinese sanctions, as the Dalai Lama's visit makes a joke of Chinese president Xi Jinping's insistence of not attaching political conditions to economic relations (Radchenko 2017). Such cases thus illustrate the embedded conditionality that come with BRI projects and further cooperation with China, where Chinese economic leverage grants it the power to coerce and influence the domestic policies of economically dependent states through the threat of sanctions at China's discretion, whenever China deems its "core interests" to have been infringed upon.

\section{Implications of the rise of China for Mongolia-Central Asia relations}

Given such opportunities and concerns surrounding the embrace of the BRI and the rise of China's clout in this region, what are their implications on the relations of Mongolia, Kazakhstan, and Kyrgyzstan among each other, all of whom directly borders China and are the first stops on its Silk Road Economic Belt? For this section, I will examine the implications of a rising China for Mongolia's foreign policies through the lens of International Relations theories on rising powers and weak state behavior, apply such theories to re-examine the current geopolitical situation of Mongolia, and then analyze the future prospects of Mongolia-Central Asia relations.

\section{On rising powers and weak state behavior:}

Substantial literature has been written on the phenomenon of rising powers and the reactions it elicits among neighboring states. The rise of China's clout, as instrumentalized through its Belt and Road Initiative, is an archetypical case of such a phenomenon, since I have demonstrated earlier that China's own power as well as 
the impact on its neighbors are absolutely increasing, while its neighbors in question have not already been previously aligned with it, thereby fitting the criteria of a new rising major power. In terms of general state behavior toward rising powers and changes in the balance of power, one key question among structural IR scholars is whether states will bandwagon (ally with the rising state), or balance (ally in opposition to the rising state). Stephen Walt (1985, pp.4-17) argued that in response to a perceived threat, the historical evidence shows that states tend to choose balancing to safeguard their self-interests more often than bandwagoning and cast their fate with the source of the perceived threat. However, he does make an exception to this pattern in the case where exceptionally weak states will be more likely to bandwagon, because they are perceived as too vulnerable and irrelevant, or when allies are simply unavailable, and if weak states see a lack of other alternatives, they will resort to bandwagoning. Meanwhile, Randall Schweller (1994) argues that Walt's position of bandwagoning as near capitulation and resigning to the threat of the liquidation of the state's independence as misleading, since states may also be motivated to bandwagon for reward - that is, lured to cooperation and alignment by the notion that bandwagoning will be beneficial and suitable to the interests of the state in its own right. Furthermore, balancing is a costly activity that most states would rather not engage unless forced to, while bandwagoning rarely involves costs, and is typically done for the expectation of gain (Schweller 1994, p.90), which can be induced when the states in question view the rising or revisionist state as the "wave of the future" - that is, as representing an inevitable IR trend that the weak state needs to join one way or another (Schweller 1994, p.96).

An especially relevant concept to Mongolia and Central Asia concerns the behavior of "weak states" in response to rising powers. Although no congruent definition of a weak state exists within the IR literature (Reeves 2014, p.254), general understandings of this concept include that such states are weak in economic (Krause \& Singer 2001), geographical (Benedict 1967; Vital 1967), or even psychological terms (Rothstein 1968) and can be an absolute or relative status compared to other states (Mosser 2001). This concept is relevant for Mongolia and Central Asia since, as Jeffrey Reeves demonstrates, Mongolia is clearly a prototypical weak state in both material and relational terms (Reeves 2014). Similarly, Kyrgyzstan's small economy and population and low state capacity (UNSD 2021) also certainly qualify it as a weak state, and although Kazakhstan exhibits greater capacities across different indicators compared to Mongolia or Kyrgyzstan (UNSD 2021) and is a significant geopolitical actor in its own right, it is, politically and economically speaking, obviously still much weaker compared to its neighbors of China and Russia and can thus also be analyzed as a weak state in the context of this analysis.

If Mongolia and Kyrgyzstan, and in this context, Kazakhstan, are indeed weak states, then what can be expected of their behavior in reaction to a rising major power-China - in their proximity? Scholars express a variety of views on the general topic of weak state behavior. Fundamentally speaking, the goal of weak states on the international scene concerns its own survival as an independent actor (Fox 1968; Pardo \& Reeves 2014). In terms of the continued achievement of this goal, there is on the one hand a binary debate between whether weak states have a predisposition to bandwagon (Rothstein 1968) or to balance (Palmer \& Morgan 2011, p.37), while 
other scholars draw attention to the concepts of weak state multilateralism or the "multi-vector" foreign policy. Annet Baker Fox argues that weak states tend to avoid balancing behavior while maintaining a benevolent neutrality toward the power they believe is on the "winning side" (Fox 1968). This is similar to Schweller's views on the "lamb" type of international actor-weak states and which do not hold revisionist foreign policy agendas, whom are the "prey of IR" and have the goal of selfabrogation in international politics, where their preferred behavior is to maintain distancing, but can also exhibit appeasement and wave-of-the future bandwagoning should the impact of the rising power prove to be irresistible (Schweller 1994, p.102). Other scholars examine weak state behavior in relation to actors other than the rising power. Keohane and Nye (2012) demonstrate that weak states see international institutions as opportunities to build coalitions and strengthen ties with other weak states (Keohane \& Nye, 2012), while Hampson Crocker \& Aall (2013) argue that weak powers seek cooperation with other weak powers to alter the existing balance of power in their favor.

A further conceptual reference for small state and weak state behavior is that of the "multi-vector" foreign policy. Arguing that small powers represent a unique type of state different from the calculations of a great power and with unique alignment decisions (Contessi 2015), scholars of post-Soviet politics in the recent decades have identified and used the concept of "multi-vectorism" to describe a common feature of foreign policies in post-Soviet states. In the context of the smaller powers of Eurasia, they identify a distinct foreign policy strand where, diverging from the standard forms of both bandwagoning and balancing, and sharing similarities with the strategies of the "third world" countries during the cold war, these smaller Eurasian states seeks to pursue close relations with different foreign powers without committing wholly to any specific partner, in order to achieve a foreign policy diversification of not becoming dependent on any single foreign power and to balance the competing interests of various foreign powers (Contessi 2015, 2018; Gnedina 2015; Clarke 2015). In such scenarios, small states engage in a "multi-vector" diplomacy, calling for the simultaneous co-alignment with different great powers, whom can represent both opportunities (sources of assistance, patronage, or prestige) and threats (dependence, dominance) in order to guarantee its national sovereignty and/ or regime survival (Contessi 2015). Such a stratagem is thus conceptually distinct from the traditional alignment notions of either bandwagoning or balancing, as it seeks to allow the weaker state to generate relational power in order to preserve autonomy while engaging in asymmetric relationships (Contessi 2018, p.763), and represents not a series of one-time transactions but a permanent, strategic approach to statecraft to ensure economic development and state security, an "organizing principle" for foreign policy as well as a domestic political tool of identity building, sovereignty consolidation, and regime legitimacy (Clarke 2015; Contessi 2018). However, one key implication of multi-vectorism is that it is a foreign policy concept rationalized in the context of an a priori conceptualization of global and regional power distribution and hence in the context of a relatively stable global balance of power. The shifting power dynamics of a rising major power thus presents major challenges to multi-vector diplomacy, because as the relative power between different foreign powers shift, the underlying power calculations for the leverage afforded 
by relationships with different vectors must also shift in order to synchronize with any changing realities.

\section{Mongolia's foreign policy in context:}

Mongolia's foreign policy behavior since the post-socialist era has thus far demonstrated significant convergences with such theories, where its policies can largely be seen as a clear example of the multi-vector approach which share key similarities with many other landlocked states of Eurasia. Reeves argues that Ulaanbaatar have since employed a foreign policy approach that seeks to engage with a rising China but attempts to limit its overall influence on its foreign and domestic affairs, as Mongolia have demonstrated no interest in bandwagoning with China, nor does it engage in antagonistic balancing against it, but rather seeks to merely dilute China's influence (Reeves 2014, p.261-262). Indeed, a major pillar of consensus for Mongolian diplomacy, fully internalized by the Mongolian political elite since the post-socialist era (Radchenko 2018, p.119), have been its "Third Neighbor Policy," where in addition to Mongolia seeking to balance relations between its two giant neighbors, China and Russia, it also seeks to cultivate ties to other powers around the world-Mongolia's "Third Neighbors"- since identified as an amalgam of Western aligned powers including the USA, countries of the Asia-Pacific rim, the EU, as well as India and Turkey (Radchenko 2018, p.111; Reeves 2014, p.262-264; Makhanov 2021, Pacheco \& Reeves 2014), Here, Mongolia seeks closer institutional ties as well as military cooperation with associated organizations such as NATO, although Ulaanbaatar is aware of the questionability of how much these relations can translate into actual support for Mongolia in the event of an actual conflict involving itself and China (Reeves 2014, p.1164). Such strategic thinking is also evident in Mongolia's "controlled risk" strategy in the economic sphere, exemplified by Mongolia's 2010 National Security Concept included a clause mandating that no foreign power can provide Mongolia with over one-third of its total foreign direct investment, where such policies are clearly formulated in response to the threat of overdependence on China (Pacheco \& Reeves 2014, p.1163), or its parliamentary law requiring Mongolia's official approval for acquisition of controlling share in the "strategic" sectors of the economy by foreign entities (Radchenko 2018, p.120). Meanwhile, while Mongolia engages with regional associations such as the Shanghai Cooperation Organization (SCO) and ASEAN Regional Forum (ARF), it does not fully join either, which can be explained, in the case of the SCO, by Mongolia's desire to maintain a certain distance from this Russia and China dominated organization thus far (Pacheco \& Reeves 2014; Radchenko 2017). Thus, establishing beneficial ties with relevant third neighbors while avoiding the dominance of either of its great power neighbors, China or Russia, forms the basis of Mongolia's foreign policy strategy, which seems to align with Schweller's conceptions of the self-abrogation goals of the "lamb" actor, and represents a textbook case of multi-vector diplomacy. 


\section{Kazakhstan and Kyrgyzstan's foreign policy in context:}

Meanwhile, an examination of the foreign policy of Kazakhstan and Kyrgyzstan in comparison with Mongolia indicates that the variances in each of their particular domestic considerations, immediate environments, state capacity, and other impacting factors contribute to the specific foreign policy manifestations currently exhibited by each country, but both these states nevertheless exhibits fundamental similarities with Mongolia in terms of the underlying self-interests and rationale of a multi-vector foreign policy as small or weak states in a common greater neighborhood.

In Kazakhstan's case, scholars illustrate how considerations for the country's domestic environment and its global geopolitical and geo-economic position shaped the country's foreign policy path following its independence from the Soviet Union in 1991. After gaining its nascent statehood, Kazakhstan's aspiring position on the world stage have since follows several major considerations: the need to construct and consolidate a distinct Kazakhstani national identity and independent statehood out of a fledgling post-Soviet state (Insebayeva 2016 p.9; Laruelle 2018); the management of its relationship with its more powerful neighbor Russia as well as the other post-Soviet Central Asian states while considering the entrenched cultural and demographic linkages as well as its geo-economic imperatives with them (Anscechi 2020; Laruelle 2018). Moreover, as the largest landlocked state in the middle of Eurasia, Kazakhstan shows aspirations for greater connectivity with the global system in order to facilitate its development goals as well as to gain greater recognition on the world stage (Kassen 2018, p.321; Laruelle 2018; Anscechi 2020, p.49). In such a context, scholars see Kazakhstan as consistently pursuing a "multi-vector" foreign policy which constructively engages Russia, China, the USA, and Europe (Laruelle 2018; Insebayeva 2016). This approach manifests in the Kazakhstan's self-conceptualization since the Nazarbayev era as an "Eurasian" country with itself being at the crossroads of Europe and Asia, a positioning which thus calls for close ties with Russia and economic integration of the post-Soviet space (Laruelle 2018; Anscechi 2020), as well as substantive engagement with both the Asia-Pacific region as well as Europe and Western nations (Laruelle 2018, p.397; Pieper 2020a). Such an Eurasianist position mirrors Kazakhstan's distancing from the more Turkic and Muslim identity as pursued by neighboring Uzbekistan under its former Karimov regime, and instead consistently prioritize Eurasian over Central Asian regional integration, rationalized in the considerations of the perceived greater economic and sociodevelopment benefits of the former option as well as to avoid the security concerns posed by the latter, despite the risk of being second-in-command to a Russian led Eurasian integration (Laruelle 2018, p.409). Nevertheless, Kazakhstan's Eurasianist path have recently became more stifled in the aftermath of the 2014 Ukrainian crisis and Russia's overly assertive push for regional integration, where concerns regarding the political weight of Russia threatens to jeopardize Nur-Sultan's multivectoral goals (Laruelle 2018; Anscechi 2020). In response to such circumstances, Laruelle analyzes Kazakhstan's exploration of a third potential foreign policy path of the "Kazakh Eli" idea, where, invoking the example of Mongolia, the country 
disassociates being part of a regional identity to instead create its own distinctive brand derived from its Kazakh ethnic identity rooted in its steppe culture historically distinct from the Transoxiana legacy of southern Central Asia, while accompanied by a greater focus toward the Asia-Pacific and takes as a model Asian countries which are seen as having attained economic modernity and cultural globalization (Laruelle 2018). Taken together, Kazakhstan's foreign policy thus represents a multi-vectoral approach of a smaller power, grounded in the landlocked Eurasian environment similar to Mongolia, but with a heightened importance and linkage of the Russia vector and a Eurasian identity looking more toward Russia. It also occupies a more middle positionality between Europe and the Asia-Pacific versus the heavy tilt of Mongolia toward the Asia-Pacific, while being on the lookout for crafting a new state identity with a greater focus toward the Asia-Pacific vector.

On the other hand, scholars illustrate the phenomena of Kyrgyzstan's foreign policy as being shaped not only by its perceived interests on the international stage but also strongly affected by the country's internal dynamics. Following its independence from the Soviet Union, Kyrgyzstan's relatively weak geopolitical and geo-economic situation shaped its perception for the need to secure assistance and opportunities from abroad to be economically viable and the provision of security in a neighborhood of instability (Sari 2012, p.138; Toktomushev 2016, p.2). Operating from conditions of structural change, uncertainty, and lack of experience of its policymakers (Sari 2012, p.131), Kemel Toktomushev argues that while on the surface, Kyrgyzstan pursues a "multi-vector" foreign policy, its actions in reality manifest in erratic, and often contradictory approaches, seeking support from often contradictory actors derided as "international beggary." He attributes such policy incoherence not only to the geopolitical and systemic weaknesses of the country, but also as a result of the country's rent seeking regimes, where the behavior of its ruling elites in this weak and kleptocratic state are dominated by the politics of rent seeking (Toktomushev 2016). In such a context, "multi-vectorism" thus becomes an act of performance rhetoric used to justify opportunistic and mercantile foreign policy deviations, largely driven by the interests of Kyrgyzstani officials as well as both Kyrgyzstani and foreign business interests rather than the interests of the Kyrgyzstani state, as evident with the whole ordeal surrounding the Manas Air Base (Toktomushev 2016). It is also being used by Kyrgyzstani ruling elites to maintain internal political order and obtain foreign support for their domestic positions (Sari 2012, p.136). Within such a context of state weakeness, it is perhaps not so surprising that Kyrgyzstan instead tends to demonstrate bandwagoning attitudes toward more powerful regional actors, such as the cases of the perceived "push" on the country to join the Russia dominated Eurasian Economic Union (Kudaibergenova 2016), or its state-led embrace of China's Belt and Road Initiative which goes against its own wearier public opinion (Mogilevskii 2019). Compared to Mongolia, Kyrgyzstan thus seems to be even more hampered by the weaknesses in its kleptocratic domestic governance in implementing its national foreign policy interests, but otherwise shares Mongolia's multi-vectoral ambitions in keeping its great power neighbors, particularly China, at arm's length. It thus seems evident that there is a convergence of fundamental foreign policy interests between all three states, which provides a foundation for their regional cooperation. 


\section{Impact of China's continued rise for Mongolia's geopolitics}

Although Mongolia's multi-vector foreign policy strategy amounts to a long-term strategic positioning, it seems evident that the continued rise of China's clout in the dawn of the BRI era represents a fundamental, ongoing shift in the balance of power within Mongolia's neighborhood, which implies changing calculations for the maintenance of the country's multi-vectoral balance. As Mongolia's period of relative political flexibility since Russia's post-cold war retrenchment and China's earlier low key foreign policy give way to an increasingly more powerful and assertive China, Radchenko questions if China's BRI ambitions will lead to Mongolia's further economic overreliance such that it will inevitably fall into Beijing's orbit, and whether Russia, itself constrained by its own dynamics of closer relations with China, will acquiesce to this eventuality (Radchenko 2017). This is thus the fundamental shift for Mongolia's geopolitical calculus: Scholars argue that Mongolia's "Third Neighbor Policy" as it currently stands is under strain in the wake of China's rise and its latest BRI, since Mongolia have currently been unable to check the country's unbalanced economic reliance on China (Hiscox 2018; Pieper 2020b; Radchenko 2017). Given such a situation, one sentiment argues for the importance of Mongolia to maintain friendly and cooperative relations with Russia, its other major neighbor, to ensure that Chinese influence in Mongolia does not gain further traction (Hiscox 2018, p.12). Ironically, a telling phenomenon on the rise of China's economic influence at the expense of Russia in Mongolia is the corresponding rise of Russia's political popularity, since Russia is no longer viewed as a potential threat even among Mongolian nationalist circles (Radchenko 2017), while the survey results show a high degree of Russia's popularity among Mongolia's general population (Center for Insights in Survey Research 2017).

Indeed, Mongolia have become increasingly friendlier toward Russia over the years, a position supported by both the more "pro-Western" and the nationalist politicians (Radchenko 2018b, p.131-133). In fact, recent developments points to a significant comeback of Mongolia's relationship with Russia, particularly since the year 2019, leading scholars to ponder if they mark the beginning of the end of Mongolia's Third Neighbor policy. They include the signing of a new treaty upgrading the Russian-Mongolian relationship to "permanent comprehensive strategic partnership" where Russia now pledged in perpetuity to "provide military-technical assistance" to Mongolia, and the increasingly materialization of the Power of Siberia-2 gas pipeline project, which is to transit Siberian gas to China through Mongolia via the planned Soyuz-Vostok pipeline section, poising to bringing huge economic and development benefits for Ulaanbaatar and further anchoring Mongolia in both China's BRI and Russia's "Greater Eurasian Partnership"-which itself envisions a merger between the Russian-led EaEU and China's BRI integration themes (Jargalsaikhan \& Radchenko 2021). The key observation here, however, is Ulaanbaatar's behavior of more coordination with the Russian side than with the Chinese side during the negotiations of this project (Gazprom 2021), which seems to demonstrate its stance of preferring Russia as 
a guarantor of integration projects over Chinese led ones. The driving force of such blossoming of Mongolia-Russia relations thus stems from Mongolia's own desire for it - thanks in part to the increasingly positive perceptions of Russia as an economic partner and well received political gestures, but also due to the key perception of Russia being a crucial counterweight against China (Jargalsaikhan \& Radchenko 2021). Still, Radchenko points out that a rising China relative not only to Mongolia but also vis-a-vis Russia means that, in the face of the growing Chinese clout, the reliability of Russia's means, if not the interest, of being a bulwark for Mongolia against Chinese domination may not be clear, as Russia itself risks becoming a junior partner in the Russia-China relationship in the long term (Radchenko 2017), while China seems certain that it will ultimately win in a long-term competition with Russia for Mongolia due to its vastly stronger economic gravity (Radchenko 2018a). Concurrently, Mongolia continues its efforts to cultivate relations with its current Third Neighbor countries, such as recent overtures with the USA or Japan (Jargalsaikhan 2018), but the reciprocation of Mongolia's outreach remains unclear, as Mongolia offers relatively little value for its identified Third Neighbors (Jargalsaikhan 2018, p.159-161; Radchenko 2017) and the payback from the Third Neighbor Policy thus far have arguably not been very impressive (Jargalsaikhan \& Radchenko 2021). Seen from the bigger picture, it thus seems that the current attempts by Mongolia to balance further Chinese influence are still yet sufficient, and perhaps calls for closer ties not only with Russia and its currently identified Third Neighbors, but also initiatives with further actors.

\section{A re-examination of Mongolia-Central Asia relations: prospects of small states regionalism-on-the Steppe}

If Mongolia's currently identified Third Neighbors are major powers in their own right but are outside of Mongolia's geopolitical neighborhood, then the Central Asian states of Kazakhstan and Kyrgyzstan represent the opposite- they are small or weak states in this context, with shared geopolitical imperatives of dealing with a rising China as well as a formerly hegemonic yet more positively viewed Russia, where these common challenges and interest alignments present opportunities and limitations for a common cause. This section will now analyze the prospects of future Mongolia-Central Asia relations.

According to theories on the response of weak states in response to rising powers as mentioned earlier, weak states can utilize different strategies to achieve its goals of safeguarding their own interests, including building coalitions with other weak states to gain greater power as a collective than going at it alone (Keohane \& Nye 2012; Hampson, Crocker \& Aall 2013). As mentioned previously, Mongolia and the Central Asian states of Kazakhstan and Kyrgyzstan already share the geopolitical motives on cooperation between each other vis-à-vis China's rise, and in theory, regionalism initiatives among them are possible given favorable political leadership as well as sufficient political and popular will among their respective societies. The possibilities of new attempts at altering the regional political landscape can already be found in the precedent of recent Central Asian 
developments such as in Uzbekistan, where the new Shavkat Mirziyoyev administration's course of reversing the country previously more isolationist stance against its neighbors and set about the prospects of a new era of Central Asian regionalism (Akromov 2020). Furthermore, just as the impetus of Uzbekistan-stimulated Central Asian regionalism is backed up by tangible measures of regional cooperation agendas (ibid), so too are multilateral relationships between Mongolia and Central Asia. First, as previously noted, Kazakhstan, Mongolia, and Kyrgyzstan are collectively the first stops on China's SREB economic corridors as necessitated by geography, so multilateral cooperation between them can theoretically endow them with much greater bargaining power vis-à-vis China as a regional bloc. This bargaining power can be utilized both in cooperation with China and as a check on Beijing's pressures. For instance, the SREB economic corridors do offer much unfulfilled potential for Mongolian and Central Asian exports to China, since there are much higher vacancies levels of cargo trains returning from Europe to China (Vinokurov et al. 2018), leaving an opportunity for Central Asian and Mongolian goods to fill the gap and, ideally speaking, fuel their important need for export diversification, which on its own can be considered as one item in a genuine "win-win" scenario for Mongolia and Central Asia. Second, the fruition of a coalition of states which are crucial for the successful realization of China's BRI objectives will afford these individual states with much more protective leverage against any actual or perceived coercive undermining of their respective sovereignties. Furthermore, greater bilateral ties, between Mongolia and Central Asian countries, themselves represent significant potential. Between Mongolia and Kazakhstan, for instance, Laruelle argues that the mutual economic interests between the two countries are promising: Kazakhstan as a source for the import of vehicles and transport equipment as well as industrial and textile machinery to Mongolia, while Mongolia may also be interested in greater Kazakhstani foreign investment, have already asked for Kazakhstan's assistance in developing its oil and electricity sector and have expressed interest toward Kazakhstan on importing wheat as well as expertise sharing of Kazakhstan's success in the construction sector and urban planning (Laruelle 2018, p.405). In pursuing such objectives, the shared "steppe identity" between Mongolia, Kazakhstan, and Kyrgyzstan may form a useful identity anchoring to facilitate such cooperation, where a common positioning of "neither, nor", 2 that is, being of an identity discursively distinct from that of Russia, of East Asia, and of the Islamic world provides an opening for the ideational development of a "Steppe Cooperation" mechanism.

Nevertheless, there are also significant concerns, limitations, and obstacles for the materialization of such "Steppe Cooperation" visions which needs to be addressed for such initiatives to gain traction. First, such new regionalism efforts, especially for Mongolia, can spell major changes for Mongolia's foreign policy principles and geopolitical alignment. Kazakhstan and Kyrgyzstan's longstanding alignment with Russia through multiple significant regionalist initiatives such as the Eurasian Economic Union (EaEU), the Collective Security Treaty Organization (CSTO), the Commonwealth of Independent States (CIS), or the Shanghai Cooperation Organization (SCO) means that regionalism with such partners likely opens the door

\footnotetext{
2 See Laruelle 2018 p.408, on the possibilities of a distinct Kazakh Eli identity, which can be a useful reference for a shared, greater Steppic identity.
} 
for Mongolia's path to greater Russian-dominated Eurasian integration, or act as a conduit for increased Russian influence in Mongolia. Such developments may thus firmly place Mongolia on a Russia-aligned path, since it is no secret that Mongolia have already long been subject to Russian pressure to join the SCO and even the EaEU (Jargalsaikhan 2018, p.161; Jargalsaikhan \& Radchenko 2021), and a Mongolia-Kazakhstan-Kyrgyzstan regionalism will certainly be a Russia-favorable one, if not subject to direct Russian influence. Indeed, since Mongolia and Central Asia does not share any direct land borders, any regional connectivity in practice have to go through either Russian or Chinese territory. If such regionalism is formed with counterbalancing China in mind, then Russia indeed assumes a dominant position as the lynchpin in such a regionalist venture, but given that Mongolia have already been willingly moving closer toward Russia recently as discussed earlier, then such implications may not necessarily be seen negatively by Ulaanbaatar. The prudence of choosing increased Russian clout over a Chinese one is up to debate, but in any case, such regionalism would mean a drastic shift from Mongolia's current neutrality principles. Second, such a move by Mongolia may also raise eyebrows with its current Third Neighbors partners-especially in the case of the USA, whom rhetorically framed cooperation with Mongolia on the basis of democratic principles and of Mongolia being an "island of democracy" in an autocratic region (Ignatov 2020), so closer association with Russia may also negatively affect Mongolia's relations with such important partners. Finally, a crucial determining factor of such endeavors lies in the dimension of the political will of Mongolia and Central Asian states to strive for its successful implementation. The charting of such a significant new chapter of relations between Mongolia and Central Asia, in the face of still low existing levels of economic, political, and people-to-people ties, will require the materialization of a significant shift in the political thinking among both the Mongolian and Central Asian political leadership in favor of such a new vision and a commitment to its execution, backed up by a sufficient level of public opinion support, in order to push through such a major foreign policy shift. The initiative here seems especially dependent on Mongolia, since it seems poised to especially benefit from its inclusion into already nascent Central Asian integration schemes and represents the side with lower bargaining power.

In sum, there are many variables in the feasibility, potential, and concerns surrounding a prospective Mongolia-Central Asia “steppe regionalism." As a weak state with a rising great power for a neighbor, the stakes for Mongolia's geopolitical destiny are growing increasingly high, but it may be forced to make its choices soon as its window of opportunities may be slowly running out, since China's growing Eurasian ambitions, temporarily disrupted by the COVID-19 crisis, seems likely to continue with renewed vigor in the post-COVID era (Asiryan 2020). The encouraging perspective, however, for Mongolia as well as Central Asian states is that they are not mere inconsequential pawns at the mercy of great powers neighbors, but that the reactions of such governments along China's new silk roads, from complementary policies, to wary embrace, to outright resistance will determine to no small extent the success of this initiative (Pieper 2020b, p.17, Bitabarova 2018). Facing a crossroads of foreign policy choices, the upcoming decisions to be taken by Mongolia and Central Asian states will, in no small part, determine their own future destinies. 


\section{Conclusion}

This article has illustrated the reasons behind the curious deficit of relations between Mongolia and Central Asian states in the face of shared geopolitical and geoeconomic imperatives, but also how China's rising clout in the region, as instrumentalized through the BRI, is changing the current equilibrium and makes closer regional relations between Mongolia and Central Asia-especially with Kazakhstan and Kyrgyzstan-deserving of a second look. Such Mongolia-Central Asia regionalism initiatives would find justifications in IR theories on weak states, rising powers, and alliance formations, yet the prospects and concerns of such a major foreign policy undertaking are multifaceted, and its implementation no easy task. Meanwhile, it seems that, over the last few years, increasing evidence of a move toward closer ties between Mongolia with Kazakhstan are appearing, such as the resumption of direct air flights and increasing agro-industrial cooperation (Erdenejargal 2019; Batchimeg 2020; Kapital.kz 2021). The crystallization of such developments into the pursuit of a concrete Mongolia-Central Asia "steppe cooperation" initiative will likely face a tough hurdle, but this does seem to represent a prudent foreign policy and identity choice for Mongolia and Central Asian states in response to their changing geopolitical environments. A scenario where such an initiative does manage to take shape will demonstrate how the agency of small or weak states can have a significant impact on the ambitions of the great powers surrounding them.

\section{Appendix}

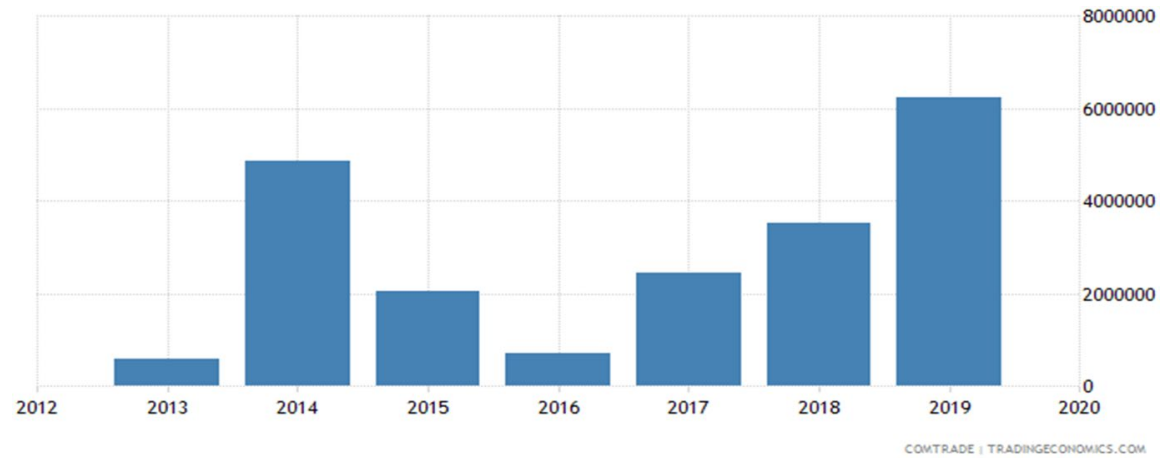

Mongolia Exports to Kazakhstan by year (value \$) (Table obtained from Tradingeconomics.com, source data from UN Comtrade) 


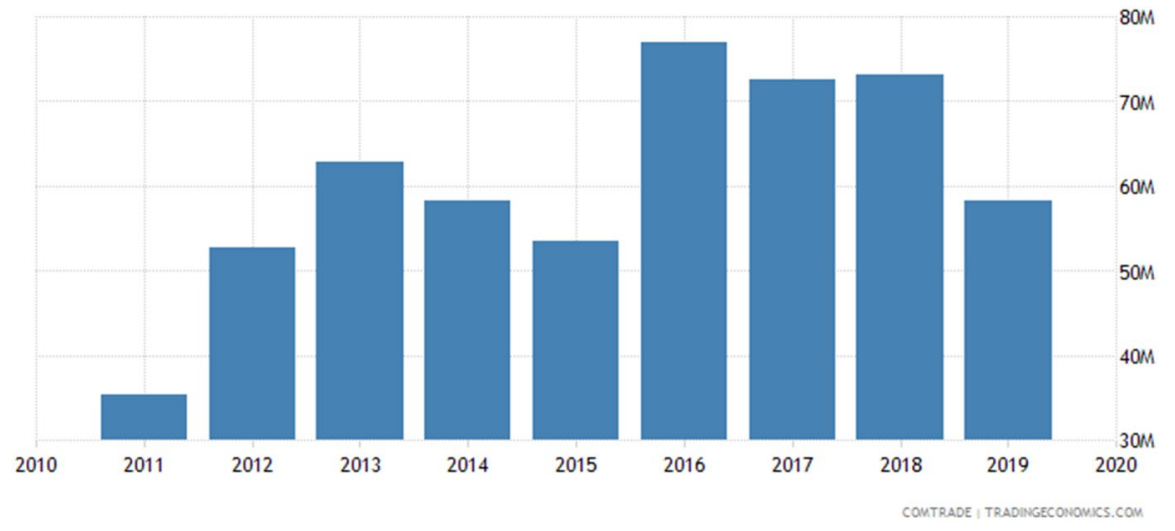

Kazakhstan exports to Mongolia by year (value \$) (ibid.)

\begin{tabular}{|c|c|c|c|c|}
\hline \multirow[t]{2}{*}{ Year } & \multicolumn{2}{|c|}{ Mongolia exports to Kazakhstan ${ }^{\mathrm{a}}$} & \multicolumn{2}{|c|}{ Kazakhstan exports to Mongolia } \\
\hline & Value & Main exported goods & Value & Main exported goods \\
\hline 2019 & $\$ 7.14 \mathrm{M}$ & $\begin{array}{l}\text { Transportation(aircraft), machines, } \\
\text { paper goods, animal products }\end{array}$ & $\$ 58.1 \mathrm{M}$ & $\begin{array}{l}\text { Foodstuffs (rolled tobacco), vegetable } \\
\text { products, animal products, machines }\end{array}$ \\
\hline 2018 & $\$ 4.04 \mathrm{M}$ & $\begin{array}{l}\text { Animal products (horse meat), } \\
\text { machines, paper goods, textiles }\end{array}$ & $\$ 70.9 \mathrm{M}$ & $\begin{array}{l}\text { Foodstuffs (rolled tobacco), vegetable } \\
\text { products (rapeseed), machines, } \\
\text { chemical products }\end{array}$ \\
\hline 2017 & $\$ 2.85 \mathrm{M}$ & $\begin{array}{l}\text { Animal products (horse meat), food- } \\
\text { stuffs, paper goods, textiles }\end{array}$ & $\$ 72.8 \mathrm{M}$ & $\begin{array}{l}\text { Foodstuffs (rolled tobacco), vegetable } \\
\text { products (rapeseed), chemical prod- } \\
\text { ucts, machines }\end{array}$ \\
\hline 2016 & $\$ 1.19 \mathrm{M}$ & $\begin{array}{l}\text { Paper goods, textiles, foodstuffs, } \\
\text { machines }\end{array}$ & $\$ 74.2 \mathrm{M}$ & $\begin{array}{l}\text { Foodstuffs (rolled tobacco), animal } \\
\text { hide (trunks and cases), chemical } \\
\text { products, vegetable products }\end{array}$ \\
\hline 2015 & $\$ 2.34 \mathrm{M}$ & $\begin{array}{l}\text { Machines (construction vehi- } \\
\text { cles), paper goods, animal } \\
\text { products }\end{array}$ & $\$ 52.1 \mathrm{M}$ & $\begin{array}{l}\text { Foodstuffs (rolled tobacco), vegetable } \\
\text { products (rapeseed), chemical prod- } \\
\text { ucts, paper goods }\end{array}$ \\
\hline 2014 & $\$ 5.03 \mathrm{M}$ & $\begin{array}{l}\text { Machines (Large construction } \\
\text { vehicles), transporation equip- } \\
\text { ment, textiles, paper goods }\end{array}$ & $\$ 59 \mathrm{M}$ & $\begin{array}{l}\text { Foodstuffs (rolled tobacco), chemical } \\
\text { products, paper goods, vegetable } \\
\text { products }\end{array}$ \\
\hline 2013 & $\$ 1.02 \mathrm{M}$ & $\begin{array}{l}\text { Paper goods, textiles, animal prod- } \\
\text { ucts, machines }\end{array}$ & $\$ 63.2 \mathrm{M}$ & $\begin{array}{l}\text { Foodstuffs, chemical products, paper } \\
\text { goods,toilet paper, petroleum coke }\end{array}$ \\
\hline
\end{tabular}




\begin{tabular}{|c|c|c|c|c|}
\hline \multirow[t]{2}{*}{ Year } & \multicolumn{2}{|c|}{ Mongolia exports to Kazakhstan ${ }^{\mathrm{a}}$} & \multicolumn{2}{|c|}{ Kazakhstan exports to Mongolia } \\
\hline & Value & Main exported goods & Value & Main exported goods \\
\hline 2012 & $\$ 1.78 \mathrm{M}$ & $\begin{array}{l}\text { Animal products, textiles, paper } \\
\text { goods }\end{array}$ & $\$ 52.8 \mathrm{M}$ & $\begin{array}{l}\text { Foodstuffs (rolled tobacco), chemical } \\
\text { products, paper goods, petroleum } \\
\text { coke }\end{array}$ \\
\hline 2011 & $\$ 1.41 \mathrm{M}$ & Animal products, textiles, & $\$ 35.4 \mathrm{M}$ & $\begin{array}{l}\text { Foodstuffs (rolled tobacco), chemical } \\
\text { products (cleaning products, paper } \\
\text { goods, wheat flours }\end{array}$ \\
\hline 2010 & $\$ 616 \mathrm{~K}$ & Textiles, animal products & $\$ 22.7 \mathrm{M}$ & $\begin{array}{l}\text { Chemical products (cleaning prod- } \\
\text { ucts), paper goods, foodstuffs, wheat } \\
\text { flours }\end{array}$ \\
\hline
\end{tabular}

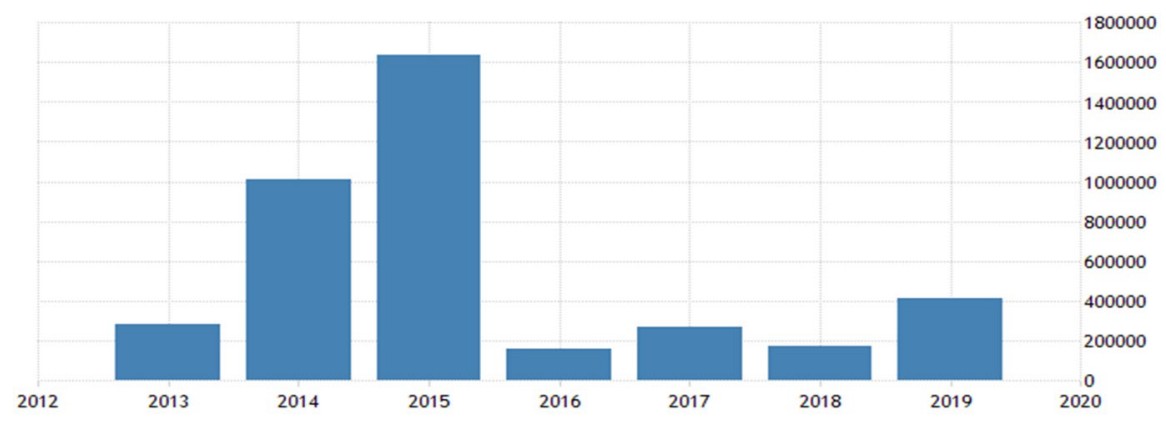

Mongolia Exports to Kyrgyzstan by year (\$) (Table obtained from Tradingeconomics.com, source data from UN Comtrade) 


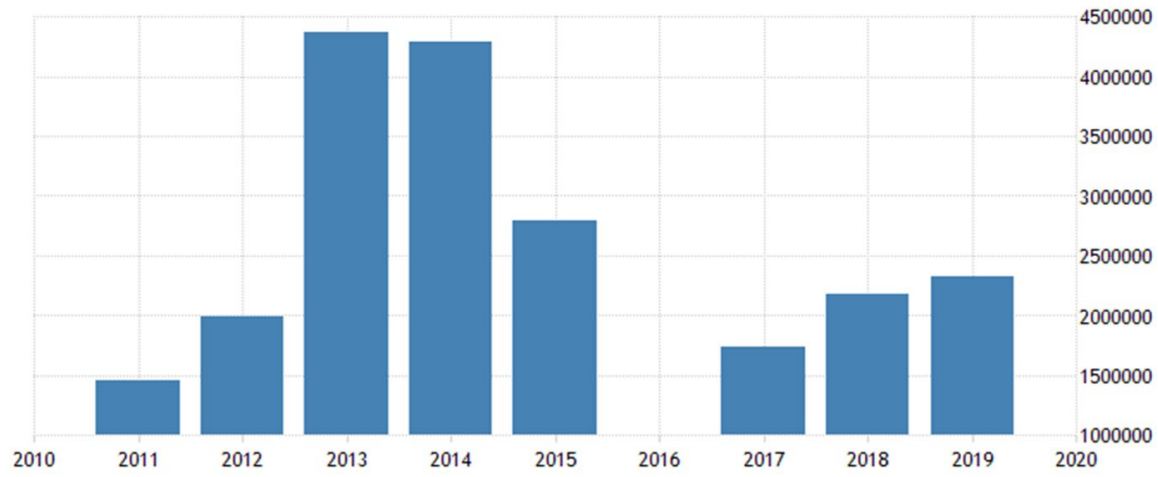

CONTRADE I TRADMGECONONICS.COM.

Kyrgyzstan exports to Mongolia by year (\$) (ibid.)

${ }^{\mathrm{a}}$ Table created with data from Observatory of Economic complexity, source data from BACI. Author's own work

\begin{tabular}{|c|c|c|c|c|}
\hline \multicolumn{3}{|c|}{ Mongolia exports to Kyrgyzstan ${ }^{\mathrm{a}}$} & \multicolumn{2}{|c|}{ Kyrgyzstan exports to Mongolia } \\
\hline Year & Value & Main exported goods & Value & Main exported goods \\
\hline 2019 & $\$ 413 \mathrm{~K}$ & Transportation (cars) & $\$ 2.39 \mathrm{M}$ & $\begin{array}{l}\text { Refined petroleum, foodstuffs (pre- } \\
\text { pared meats, baked goods), cars }\end{array}$ \\
\hline 2018 & $\$ 255 \mathrm{~K}$ & Animal products, textiles & $\$ 2.35 \mathrm{M}$ & $\begin{array}{l}\text { Refined petroleum, foodstuffs (pre- } \\
\text { pared meats, baked goods) }\end{array}$ \\
\hline 2017 & $\$ 269 \mathrm{~K}$ & Molybdenum ore, textiles & $\$ 1.75 \mathrm{M}$ & $\begin{array}{l}\text { Refined petroleum, Foodstuffs (pre- } \\
\text { pared meats, baked goods) }\end{array}$ \\
\hline 2016 & $\$ 401 \mathrm{~K}$ & Feldspar, molybdenum ore, & $\$ 2.94 \mathrm{M}$ & $\begin{array}{l}\text { Refined petroleum, Foodstuffs } \\
\text { (prepared meats, chocolates), blank } \\
\text { audio media }\end{array}$ \\
\hline 2015 & $\$ 1.68 \mathrm{M}$ & Feldspar, molybdenum ore & $\$ 2.85 \mathrm{M}$ & Refined petroleum, cars, foodstuffs \\
\hline 2014 & $\$ 1.01 \mathrm{M}$ & Feldspar & $\$ 4.29 \mathrm{M}$ & Refined petroleum, cars, foodstuffs \\
\hline 2013 & $\$ 338 \mathrm{~K}$ & $\begin{array}{l}\text { Feldspar, used rubber tires, insect } \\
\text { resins }\end{array}$ & $\$ 4.37 \mathrm{M}$ & Refined petroleum, cars, foodstuffs \\
\hline 2012 & $\$ 965 \mathrm{~K}$ & Feldspar & $\$ 1.99 \mathrm{M}$ & $\begin{array}{l}\text { Foodstuffs (processed tobacco), } \\
\text { refined petroleum, vegetable } \\
\text { products }\end{array}$ \\
\hline 2011 & $\$ 410 \mathrm{~K}$ & Feldspar, & $\$ 1.46 \mathrm{M}$ & $\begin{array}{l}\text { Foodstuffs (processed tobacco), } \\
\text { machines, cars }\end{array}$ \\
\hline 2010 & $\$ 362 \mathrm{~K}$ & Feldspar & $\$ 1.99 \mathrm{M}$ & Foodstuffs (processed tobacco) \\
\hline
\end{tabular}




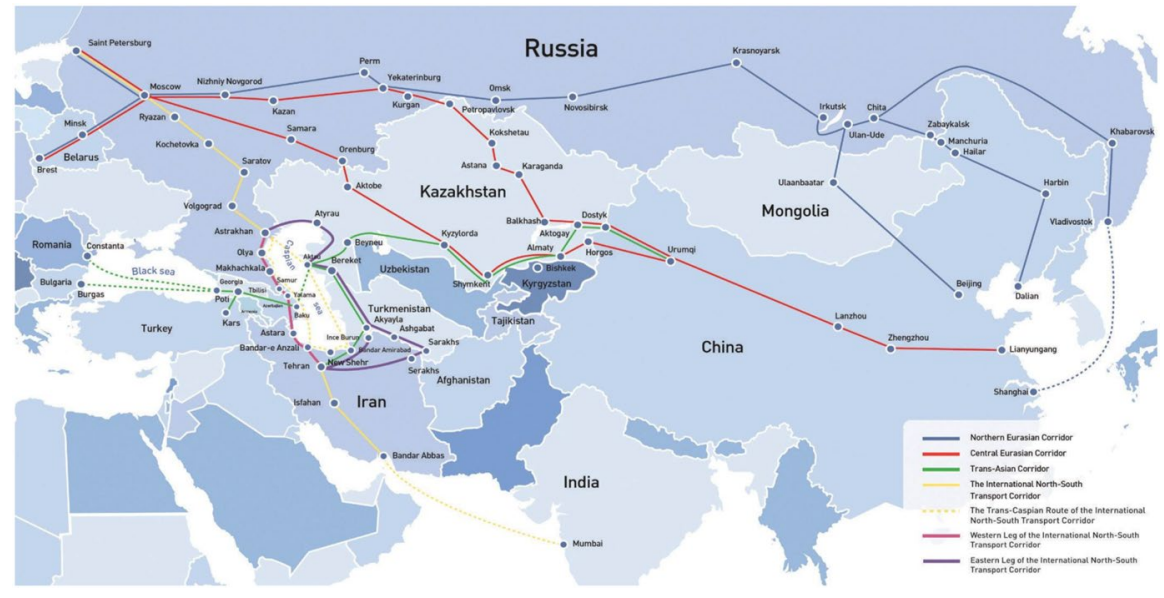

Illustration (from Vinokurov et al. 2018)

${ }^{a}$ Table created with data from Observatory of Economic complexity, source data from BACI. Author's own work

Acknowledgements The author acknowledges financial support from the Fonds voor Wetenschappelijk Onderzoek-Vlaanderen (FWO) Flemish Research Foundation (FWO research project G039220N).

Funding Fonds Wetenschappelijk Onderzoek, G039220N, John Irgengioro.

\section{Declarations}

Conflict of interest The authors delcare that they have no Conflict of interest.

\section{References}

Akromov, Otabek. 2020. "Uzbekistan`s New Foreign Policy: Rekindling Regional Ties in Central Asia." Atlas Institute for International Affairs. https://www.internationalaffairshouse.org/uzbekistansnew-foreign-policy-rekindling-regional-ties-in-central-asia/

Anceschi, Luca. 2020. Analysing Kazakhstan's Foreign Policy: Regime Neo-Eurasianism in the Nazarbaev Era. 1st edn. Abingdon, Oxon; New York, NY : Routledge, 2020. I Series: Central Asia research forum: Routledge.

Artman, Vincent M. 2019. 'My Poor People, Where Are We Going?': Grounded Theologies and National Identity in Kyrgyzstan. Europe-Asia Studies 74 (10): 1734-1755.

Asiryan, Aleksey. 2020. "Post-COVID, China Set to Gain in Central Asia." The Diplomat. https://thedi plomat.com/2020/07/post-covid-china-set-to-gain-in-central-asia/

Baabar, B. 1995. The Central Asian Security Zone. Mongolian Journal of International Affairs 2: 14-25.

Badral, D. 2017. "ПЕРСПЕКТИВЫ ПОЛИТИЧЕСКОГО ВЗАИМОДЕЙСТВИЯ КЫРГЫЗСКОЙ РЕСПУБЛИКИ И МОНГОЛИИ” (Prospects for political cooperation between the Kyrgyz Republic and Mongolia). Проблемы современной науки и образования(Problems of Modern Science and Education), 111-114

Batbayar, Tsedendamba. 2002. Geopolitics and Mongolia's Search for Post-Soviet Identity. Eurasian Geography and Economics 43 (4): 323-335. 
Batchimeg, B. 2019. "Embassy of Mongolia in the Kyrgyz Republic Opens." MONTSAME News Agency. https://www.montsame.mn/en/read/192611

Batchimeg. 2020. "Zhalgas Adilbayev: Kazakhstan and Mongolia Have Not Fully Used Their Cooperation Potentials." MONTSAME News Agency. https://montsame.mn/en/read/222694

Benedict, Burton. 1967. Problems of Smaller Territories. London: Athlone Press.

Billé, Franck. 2010. Sounds and Scripts of Modernity: Language Ideologies and Practices in Contemporary Mongolia. Inner Asia 12 (2): 231-252.

Bitabarova, Assel G. 2018. Unpacking Sino-Central Asian Engagement along the New Silk Road: A Case Study of Kazakhstan. Journal of Contemporary East Asia Studies 7 (2): 149-173.

Bizhanova, Madina. 2018. "Can the Silk Road Revive Agriculture? Kazakhstan's Challenges in Attaining Economic Diversification. In China's Belt And Road Initiative And Its Impact in Central Asia, ed. Marlène Laruelle, 51-66. Central Asia Program: George Washington University.

Center for Insights in Survey Research. 2017. Pre-Presidential Election National Survey of Mongolian Public Opinion. International Republican Institute. http://www.iri.org/resource/poll-amidst-persi stent-economic-woes-mongolians-want-political-change

Chatzky, Andrew, and James McBride. 2019. "China's Massive Belt and Road Initiative." Council on Foreign Relations. https://www.cfr.org/backgrounder/chinas-massive-belt-and-road-initiative

Chen, Yu-Wen. 2015. A Research Note on Central Asian Perspectives on the Rise of China: The Example of Kazakhstan. Issues \&amp; Studies 51 (3): 63-87.

China National Bureau of Statistics. 2019. China National Data. https://data.stats.gov.cn/easyquery.htm? $\mathrm{cn}=\mathrm{C} 01 \& \mathrm{zb}=\mathrm{A} 0 \mathrm{~K} 01 \& \mathrm{sj}=2018$

Chubarov, Ilya. 2019. Challenges and Opportunities for the Spatial Development of Eurasia under the BRI: The Case of the Eurasian Economic Union. Area Development and Policy 4 (1): 81-97.

Clarke, Michael. 2015. "Kazakhstan's Multi-Vector Foreign Policy: Diminishing Returns in an Era of Great Power 'Pivots'?" The Asan Forum. https://theasanforum.org/kazakhstans-multi-vector-forei gn-policy-diminishing-returns-in-an-era-of-great-power-pivots/ (November 21, 2021).

Cohen, Roger. 2005. English in Mongolia. World Englishes 24 (2): 203-216.

Contessi, Nicola P. 2015. Foreign and Security Policy Diversification in Eurasia: Issue Splitting, CoAlignment, and Relational Power. Problems of Post-Communism 62 (5): 299-311.

Contessi, Nicola P. 2018. Foreign Policy Diversification and Intercontinental Transport Corridors: The Case of Kazakhstan's Railways Diplomacy. Europe-Asia Studies 70 (5): 759-790.

Cooley, Alexander. 2016. "The Emerging Political Economy of OBOR: The Challenges of Promoting Connectivity in Central Asia and Beyond." Center for Strategic \& International Studies. p.1-16

Enkh-Orgil. 2017. "Mongolian Kazakh students to study in Kazakhstan." News.MN. https://news.mn/en/ 512138/ (April 27, 2021).

Erdenejargal, E. 2019. "Zhalgas Zh. Adilbayev: Mongolia-Kazakhstan Relations Advanced to New Level.” MONTSAME News Agency. https://www.montsame.mn/en/read/204851

Fallon, Theresa. 2015. The New Silk Road: Xi Jinping's Grand Strategy for Eurasia. American Foreign Policy Interests 37 (3): 140-147.

Fox, Annette Baker. 1968. The Small States in the International System, 1919-1969. International Journal 24 (4): 751-764.

Gazprom. 2021. "Gazprom and the Government of Mongolia discussed the progress of the feasibility study for the Soyuz Vostok gas pipeline.” PR Gazprom. https://www.gazprom.ru/press/news/2021/ october/article540770/

Gnedina, Elena. 2015. 'Multi-Vector' Foreign Policies in Europe: Balancing, Bandwagoning or Bargaining? Europe-Asia Studies 67 (7): 1007-1029.

Grieger, Gisela. 2015. China's leading role in the Shanghai Cooperation Organization. Briefing, EuropeanParliament. http://www.europarl.europa.eu/RegData/etudes/BRIE/2015/564367/EPRS_ BRI(2015)564367_EN.pdf

Higgins, Andrew. 2019. "A Power Plant Fiasco Highlights China’s Growing Clout in Central Asia." The New York Times. https:/www.nytimes.com/2019/07/06/world/asia/china-russia-central-asia.html (December 21, 2021).

Hiscox, Amy. 2018. Modern Mongolia: Geopolitics amid great powers. Culture Mandala: Belletin of the Centre for East-West Cultural and Economic Studies 13 (1): 1-15.

Ignatov, Ivan. 2020. US Policy Towards Mongolia Within the Context of Mongolia's "third neighbor" Concept. USA \&amp; Canada: Economika, Politika, Cultura. 9: 44-57. 
Imanaliyeva, Ayzirek. 2020. "Kyrgyzstan: Living in the Shadow of a Sleeping Chinese Oil Refinery." Eurasianet. https://eurasianet.org/kyrgyzstan-living-in-the-shadow-of-a-sleeping-chinese-oil-refin ery

Insebayeva, Sabina. 2016. Imagining the Nation: Identiy, Nation Building and Foreign Policy in Kazakhstan. Central Asia Program.

ICEF Monitor. 2019. "Mongolian Outbound Higher than Estimated, Most of It Going to Asian Powerhouses." ICEF Monitor - Market intelligence for international student recruitment. https://monit or.icef.com/2019/09/mongolian-outbound-higher-than-estimated-most-of-it-going-to-asian-power houses/

Jargalsaikhan, Mendee, and Sergey Radchenko. 2021. "Mongolia: Russia's Best Friend in Asia?" The Asan Forum (Special Forum Issue: Looking back on Putin's "Turn to the East" over a decade). https://theasanforum.org/mongolia-russias-best-friend-in-asia/ (November 21, 2021).

Jargalsaikhan, Mendee. 2018. Mongolia's Dilemma: A Politically Linked, Economically Isolated Small Power". In International Relations and Asia's Northern Tier: Sino-Russia Relations, North Korea, and Mongolia, ed. Rozman Gilbert and Sergey Radchenko, 157-174. Singapore: Springer.

Kapital.kz. 2021. "For 7 Months, Commodity Turnover in the Agro-Industrial Complex between Kazakhstan and Mongolia Amounted to \$ 7.2 Million.” Деловой портал Капитал.кз. https://kapital.kz/ economic/99741/za-7-mesyatsev-tovarooborot-v-apk-mezhdu-kazakhstanom-i-mongoliyey-sosta vil-7-2-mln.html

Kassen, Maxat. 2018. Understanding Foreign Policy Strategies of Kazakhstan: A Case Study of the Landlocked and Transcontinental Country. Cambridge Review of International Affairs 31 (3-4): 314-343.

Kazakhstan Ministry of Foreign Affairs. 2021. "Kazakhstan-Mongolia”. Retrieved April http://mfa.gov. kz/en/content-view/sotrudnicestvo-respubliki-kazakhstan-s-mongoliej

Keohane, Robert, and Joseph S. Nye. 2012. Power and Interdependence. Boston, MA: Longman.

Kivimaki, Timo. 2014. Soft Power and Global Governance with Chinese Characteristics. The Chinese Journal of International Politics 7 (4): 421-447.

Kohn, Michael. 2016. "Mongolia Vows No More Dalai Lama Visits After China Turns Screws.” Bloomberg.com. https://www.bloomberg.com/news/articles/2016-12-21/mongolia-vows-no-more-dalailama-visits-after-china-turns-screws (April 22, 2021).

Korea Tourism Association. 2019. "Korea, Monthly Statistics of Tourism I Key Facts on Tourism I Tourism Statistics.” http://kto.visitkorea.or.kr/eng/tourismStatics/keyFacts/KoreaMonthlyStatistics/eng/ inout/inout.kto

Krapohl, Sebastian, and Alexandra Vasileva-Dienes. 2020. The Region That Isn't: China, Russia and the Failure of Regional Integration in Central Asia. Asia Europe Journal 18 (3): 347-366.

Krause, Volker, and J. David. Singer. 2001. Minor Powers, Alliances, and Armed Conflicts: Some Preliminary Patterns. In Small States and Alliances, ed. E. Reiter and H. Gartner, 15-25. New York: Springer.

Kruglov, Alexander. 2019. "Sinophobia Simmers across Central Asia." Asia Times. https://asiatimes.com/ 2019/11/sinophobia-simmers-across-central-asia/ (April 20, 2021).

Kudaibergenova, Diana T. 2016. Eurasian Economic Union Integration in Kazakhstan and Kyrgyzstan. European Politics and Society 17 (sup.1): 97-112.

Laruelle, Marlene. 2014. Russia and Central Asia. EUCAM 17: 5.

Laruelle, Marlene. 2018. "Kazakhstan's Dilemma on Eurasian and Central Asian Integrations. In Central Asia in the Era of Sovereignty: The Return of Tamerlane?, ed. Daniel L. Burghart and Theresa Sabonis-Helf, 395-414. Lanham: Lexington Books.

Laruelle, Marlene. 2019. The Nazarbayev Generation. Lexington Books.

Makhanov, Kanat. 2021. "Turkey's place in Mongolia's “Third Neighbor" Policy". In: Trade between Turkey and Central Asia. Asia-Evropa. 22-29

Mayer, Maximilian. 2018. Rethinking the Silk Road. Singapore: Springer.

Millward, James A. 2007. Eurasian Crossroads: A History of Xinjiang. Columbia University Press.

Mogilevskii, Roman. 2019. "Kyrgyzstan and the Belt and Road Initiative." SSRN Electronic Journal. Working Paper \#50

Mosser, Michael M. 2001. Engineering Influence: The Subtle Power of Small States in the CSCE/OSCE. In Small States and alliances, ed. E. Reiter and H. Gartner, 63-85. New York: Springer.

Myadar, Orhon, and James Deshaw Rae. 2019. Territorializing National Identity in Post-Socialist Mongolia: Purity, Authenticity, and Chinggis Khan. Eurasian Geography and Economics 55 (5): $560-577$. 
National Statistics Committee of Kyrgyzstan. 2017. Tourism in Kyrgyzstan 2013-2017.

Observatory of Economic Complexity "Mongolia (MNG) Exports, Imports, and Trade Partners." https:// oec.world/en/profile/country/mng (April 26, 2021c).

Observatory of Economic Complexity "Kyrgyzstan (KGZ) Exports, Imports, and Trade Partners." https:// oec.world/en/profile/country/kgz (April 26, 2021b).

Observatory of Economic Complexity. "Kazakhstan (KAZ) Exports, Imports, and Trade Partners." https://oec.world/en/profile/country/kaz (April 26, 2021a).

Olzvoy, K. 1996. A Mongol's View On Economic Development and Cooperation in Northeast Asia. Mongolian Journal of International Affairs 3: 50-55.

Hampson, Osler Fen, Chester A. Crocker, and Pamela Aall. 2013. "Negotiation". In: "The Oxford Handbook of Modern Diplomacy." ed. Andrew F. Cooper, Jorge Heine, and Ramesh Thakur. Oxford Handbooks Online, 1-14

Pacheco Pardo, Ramon, and Jeffrey Reeves. 2014. Weak Power Bargaining with China: Mongolia and North Korea in Comparative Perspective. Journal of Contemporary China 23 (90): 1152-1173.

Palmer, Glenn, and T. Clifton Morgan. 2011. Theory of Foreign Policy. Princeton, NJ: Princeton University Press.

Pantucci, Raffaello. 2015. "Looking West: China and Central Asia." US-China Economic and Security Review Commission, China in Central Asia, 16

Pantucci, Raffaello, and Sarah Lain. 2017. China's Eurasian Pivot: The Silk Road Economic Belt. Royal United Services Institute for Defence and Security Studies.

Pieper, Moritz. 2020b. The New Silk Road Heads North: Implications of the China-Mongolia-Russia Economic Corridor for Mongolian Agency within Eurasian Power Shifts. Eurasian Geography and Economics, $1-24$.

Pieper, Moritz. 2020a. The Linchpin of Eurasia: Kazakhstan and the Eurasian Economic Union between Russia's Defensive Regionalism and China's New Silk Roads. International Politics 58 (3): $462-482$.

Radchenko, Sergey. 2017. "Mongolia's Shrinking Foreign Policy Space I The Asan Forum." http:// www.theasanforum.org/mongolias-shrinking-foreign-policy-space/

Radchenko, S. 2018a. Sino-Russian Competition in Mongolia. In International Relations and Asia's Northern Tier: Sino-Russia Relations, North Korea, and Mongolia, ed. Rozman Gilbert and Sergey Radchenko, 111-125. Singapore: Springer.

Radchenko, S. 2018b. Mongolia Hangs in the Balance: Political Choices and Economic Realities in a State Bounded by China and Russia. In International Relations and Asia's Northern Tier: Sino-Russia Relations, North Korea, and Mongolia, ed. Rozman Gilbert and Sergey Radchenko, 127-146. Singapore: Springer.

Reeves, Jeffrey. 2014. Rethinking Weak State Behavior: Mongolia's Foreign Policy toward China. International Politics 51 (2): 254-271.

RFE/RL. 2020. "Hundreds Join Protests Against Chinese Investment In Kyrgyzstan." RadioFreeEurope/RadioLiberty. https://www.rferl.org/a/30439686.html

Rickleton, Chris .2020. "Kazakhstan Squeezes China Critics as Xinjiang Anxieties Spread." Eurasianet. https://eurasianet.org/kazakhstan-squeezes-china-critics-as-xinjiang-anxieties-spread

Rickleton, Chris 2021. "After Tentative Start, Kazakhstan Is Obliterating Xinjiang Activism." Eurasianet. https://eurasianet.org/after-tentative-start-kazakhstan-is-obliterating-xinjiang-activism

Rothstein, Robert. 1968. Alliance and Small Powers. New York: Columbia University Press.

Sari, Yasar. 2012. Foreign Policy of Kyrgyzstan Under Askar Akayev and Kurmanbek Bakiyev. Perceptions Journal of International Affairs 17 (3): 131-150.

Schweller, Randall. 1994. Bandwagoning for Profit: Bringing the Revisionist State Back In. International Security 19 (1): 72-107.

Skalamera, Morena. 2017. Russia's Lasting Influence in Central Asia. Survival 59 (6): 123-142.

Soni, Sharad K. 1996. Perspectives on Mongolia: Central Asia Relations. Jadavpur Journal of International Relations 2 (1): 173-179.

Standish, Reid. 2021. "How Will Kyrgyzstan Repay Its Huge Debts To China?" RadioFreeEurope/ RadioLiberty. https://www.rferl.org/a/how-will-kyrgyzstan-repay-its-huge-debts-to-china-/ 31124848.html (April 14, 2021).

S, Starr 2008 In Defense of Greater Central Asia." Central Asia-Caucasus Institute \& Silk Road Studies Program. John Hopkins Universit

Stat.gov.kz. 2021. “Бюро Национальной Статистики.” https://stat.gov.kz/ 
Stat.kg. 2021. "Education and Culture-Official Statistics-Statistics of the Kyrgyz Republic." http:// stat.kg/en/statistics/obrazovanie/

Toktomushev, Kemel. 2017. Kyrgyzstan-Regime Security and Foreign Policy. Routledge.

Umirbekov, Darkhan. 2019. “Kazakhstan: Sinophobic Sentiments Trigger Fresh Rallies.” Eurasianet. https://eurasianet.org/kazakhstan-sinophobic-sentiments-trigger-fresh-rallies (April 28, 2021).

UN Comtrade. 2021. "Mongolia Metadata" https://unstats.un.org/wiki/display/comtrade/Mongolia+ Metadata

UNSD. 2021. "United Nations Statistics Division — Methodology." https://unstats.un.org/unsd/metho dology/m49/

Van Der Kley, Dirk. 2021. "China Diversifies in Central Asia.” Eurasianet. https://eurasianet.org/ china-diversifies-in-central-asia

Vinokurov, Evgeny, Vitaly Lobyrev, Andrey Tikhomirov, and Taras Tsukarev. 2018. "Belt and Road Transport Corridors: Barriers and Investments." Eurasian Development Bank, Institute of Economy and Transport Development

VisitUlaanbaatar. 2019. “Монгол Улс 2019 Онд 577 Мяанган Жуулчин Хулээн Авлаa.” https:// tourism.ub.gov.mn/?p=8819

Vital, D. 1967. The Inequality of States. New York: Oxford University Press.

Walt, Stephen M. 1985. Alliance Formation and the Balance of World Power. International Security 9 (4): 3-43.

Wang, Jisi. 2011. China's Search for a Grand Strategy: A Rising Great Power Finds Its Way. Council on Foreign Relations 90 (2): 68-79.

Wilson, Jeanne L. 2015. Russia and China Respond to Soft Power: Interpretation and Readaptation of a Western Construct. Politics 35 (3-4): 287-300.

World Bank. 2021. "World Bank Country and Lending Groups_-World Bank Data Help Desk." https:// datahelpdesk.worldbank.org/knowledgebase/articles/906519-world-bank-country-and-lendinggroups (April 27, 2021).

Yau, Niva. 2019. "Branding the Belt and Road: Beijing Embarks on Damage Control in Central Asia." Eurasianet. https://eurasianet.org/branding-the-belt-and-road-beijing-embarks-on-damage-controlin-central-asia

Yau, Niva. 2020. "China Business Briefing: Not Happy with Kyrgyzstan.” Eurasianet. https://eurasianet. org/china-business-briefing-not-happy-with-kyrgyzstan (April 28, 2021).

Yemelianova, G. M. 2014. Islam, national identity and politics in contemporary Kazakhstan. Asian Ethnicity 15 (3): 286-301.

Publisher's Note Springer Nature remains neutral with regard to jurisdictional claims in published maps and institutional affiliations. 